\title{
Chemical Studies on the Ocean-LXV. \\ Chemical Studies of the Shallow-water Deposits-18.
}

\section{On the Chemical Constituents of the Shallow-water Deposits along the Sea-coasts of Osaka, Kyoto and Fukui Prefectures, and the Generalized Consideration of the Shallow-water Deposits in Japan Proper*}

\author{
Shunzō UEDA**
}

\begin{abstract}
In this paper, the results of analysis, carried out laying emphasis on $\mathrm{K}$, of 10 kinds of the deposits collected from the sea-coasts of Ōsaka, Kyōto and Fukui Prefectures, are described, and further, the generalized considerations of all the samples from all the sea-coasts of Japan Proper are presented. From the summarized results of all samples, it is found that the $\mathrm{K}_{2} \mathrm{O}$ content is exceedingly high in those from Hiroshima, Yamaguchi and Shimane Prefectures, especially so in the deposits from Hiroshima, while it is exceedingly low in many of the deposits from Aomori, Miyagi, Chiba, Kanagawa, Wakayama, Mie, Fukui Prefectures and the like, especially so in those collected at Sagami Bay.
\end{abstract}

\section{Introduction}

In the previous paper (UEDA, 1956 a), the author has reported on the chemical composition of 9 kinds of the deposits from the sea-coasts of Miyagi, Fukushima and Ibaraki Prefectures. In this paper, the analytical results of 10 kinds of deposits from the sea-coasts of Ōsaka, Kyōto and Fukui Pre-

* This investigation was partly presented at the 5 th Annual Meeting of the Chemical Society of Japan, Tokyo, on April 6, $1952 . \quad$ Received July 30, 1956.

** Faculty of Technology, Kanazawa University fectures are described, and further, summarizing these results and all other results already reported (ISHIBASHI and UEDA, 1956 $\mathrm{a}, \mathrm{b}, \mathrm{c}, \mathrm{d}, \mathrm{e}, \mathrm{f}, \mathrm{g}$; ISHI ?ASHI, UEDA and YAмАмото 1956; UEDA, $1956 \mathrm{a}, \mathrm{b}, \mathrm{c})$, the generalized considerations concerning all the samples (110 kinds) from all the sea-coasts of Japan Proper are presented.

\section{Samples}

Locality and date of sampling are shown in Table 1.

Table 1. Locality and date of sampling.

\begin{tabular}{|c|c|c|c|c|}
\hline Sample No. & Locality & \multicolumn{3}{|c|}{ Date } \\
\hline 101 & Yoshimi, Tajirimura, Sennangun, Ösakafu & Aug. & 25 , & 1947 \\
\hline 110 & Kamiyamachi, Kishiwadashi, Ösakafu & Aug. & 15 , & 1948 \\
\hline 102 & Shiomimachi, Izumiōtsushi, Ōsakafu & Aug. & 26 , & 1947 \\
\hline 103 & Hamazumemura, Takenogun, Kyōtofu & Aug. & 18 , & 1947 \\
\hline 104 & Iwagahana, Yōrōmura, Yozagun, Kyōtofu & Sept. & 15 , & 1948 \\
\hline 109 & Shimasaki, Miyazumachi, Yozagun, Kyōtofu & Aug. & 2, & 1947 \\
\hline 105 & Higashikanzaki, Kanzakimura, Kasagun, Kyōtofu & Aug. & 24 , & 1948 \\
\hline 106 & Wakamiya, Takahamamachi, Ōigun, Fukuiken & Aug. & 1 , & 1947 \\
\hline 107 & Shirahige, Obamamachi, Onyūgun, Fukuiken & Sept. & 30. & 1947 \\
\hline 108 & Ishishinbo, Natsumemura, Sakaigun, Fukuiken & Sept. & 25 , & 1947 \\
\hline
\end{tabular}


All of these samples are the deposits collected in the neighbourhoood of the shoreline.

Sample 101: yellowish brown sand; collected by K. SAKAI at the point about $700 \mathrm{~m}$ northeast of the estuary of the Kashii River.

Sample 110: yellowish brown sand containing many gravels; collected by E. TAKAO at the point about $1 \mathrm{~km}$ northeast of the estuary of the 'Tsuda River.

Sample 102: light yellowisi brown sand; collected by N. Morita at the point about $500 \mathrm{~m}$ northeast of the estuary of the Ōtsu River.

Sample 103: light brown sand containing shell fragments; collected by K. KanAmasu at the point about $700 \mathrm{~m}$ northeast of the estuary of the Kizu River.

Sample 104: light brown sand; collected by M. NodA at the point about $400 \mathrm{~m}$ northeast of the estuary of the Sai River.

Sample 109: yellowish brown sand; collected by $\mathrm{K}$. ŌंsuKA at the point about $100 \mathrm{~m}$ northwest of the estuary of the Öte River.

Sample 105: light brownish gray sand; collected by $\mathrm{Y}$. TsujI at the point about $1 \mathrm{~km}$ southeast of the estuary of the Yura River.

Sample 106: greenish black sand containing shell fragments and many small gravels; collected by $\mathrm{S}$. Moritsugu at the point about $2.8 \mathrm{~km}$ southeast of the estuary of the Sekiya River.

Sample 107: grayish brown sand ; collected by Y. Mizue at the point about $1.3 \mathrm{~km}$ southwest of the estuary of the Minami River.

Sample 108: brown sand; collected by $\mathrm{S}$. FujITA at the sea-coast of Ishishinbo.

The size composition of these samples is shown in Table 2.

The geology of the land adjacent to the locations sampled is briefly as follows*:

In Ōsaka districts, granites distribute only at the eastern and southern margins, and most parts are composed of Quaternary formutions.

* The parentheses are for the rocks and formations which distribute in the land areas not so far from the location of collection.
Table 2. Size composition of the deposits.

\begin{tabular}{|c|c|c|c|c|c|c|c|}
\hline Sample No. & $>8$ & 14 & 28 & 48 & 100 & 200 & pan \\
\hline 101 & $\begin{array}{l}\% \\
6\end{array}$ & $13^{\%}$ & 76 & $\%$ & $\begin{array}{l}\% \\
0\end{array}$ & $\begin{array}{l}\% \\
0\end{array}$ & $\begin{array}{l}\% \\
0\end{array}$ \\
\hline 110 & 56 & 16 & 25 & 2 & 0 & 1 & 0 \\
\hline 102 & 5 & 3 & 17 & 45 & 29 & 1 & 0 \\
\hline 103 & 0 & 0 & 1 & 30 & 69 & 1 & 0 \\
\hline 104 & 14 & 6 & 38 & 27 & 12 & 3 & 0 \\
\hline 109 & 5 & 31 & 34 & 19 & 9 & 2 & 0 \\
\hline 105 & 0 & 0 & 7 & 58 & 33 & 2 & 0 \\
\hline 106 & 67 & 26 & 7 & 0 & 0 & 0 & 0 \\
\hline 107 & 10 & 30 & 37 & 19 & 4 & 0 & 0 \\
\hline 108 & 0 & 2 & 77 & 20 & 1 & 0 & 0 \\
\hline
\end{tabular}

(a) Tyler standard.

Sample 101: Quaternary formations. The Kashii River which pours into the sea near the location, runs mainly through the Mesozoic formations, quartz-porphyry and graniteporphyry.

Samples 110 and 102: Quaternary formations. The Tsuda and Ōtsu Rivers which pour near the locations, run mainly through granites.

As for Kyōto and Fukui Prefectures, Paleozoic formations distribute widely in the districts surrounding Wakasa Bay, and granites develop in Yoza Peninsula and in the neighbourhood of Tsuruga.

Sample 103: Tertiary formations; (Quaternary formations).

Sample 104: Tertiary formations; (andesite).

Sample 109: Quaternary formations; (granites).

Sample 105: Paleozoic formations. The Yura River which pours into the sea near the location, runs mainly through Paleozoic formations, diorite and Mesozoic formations.

Sample 106: diorite.

Sample 107: Paleozoic formations and Quaternary formations.

Sample 108: Quaternary formations; (andesite and Tertiary formations).

\section{Experimental Procedure, Results and Discussion}

Experiments were carried out as described previously (Ishibashi and UEda, 1956 a). 
The analytical results of the air-dried samples are shown in Table 3. From this table we obtained the percentages of chemical constituents in the sea-salt-free samples dried at $105 \sim 110^{\circ} \mathrm{C}$ as shown in Table $4^{*}$.

As obvious from Table 4, all deposits from Ōsaka Bay, that is, Samples 101, 110 and 102, and some of the deposits from Wakasa Bay,

Table 3. Chemical composition of the deposits.

\begin{tabular}{|c|c|c|c|c|c|c|c|c|c|c|}
\hline Sample No. & 101 & 110 & 102 & 103 & 104 & 109 & 105 & 106 & 107 & 108 \\
\hline Drying loss & $0.55^{\%}$ & $0.38^{\%}$ & $0.58^{\%}$ & $0.89^{\%}$ & $0.75^{\%}$ & $0.40^{\%}$ & $0.67^{\%}$ & $0.4 \%$ & $0.32^{\%}$ & $0.56 \%$ \\
\hline Ignition loss & 1.15 & 1.28 & 1.11 & 5.19 & 1.00 & 0.89 & 1.64 & 5.62 & 1.32 & 1.69 \\
\hline $\mathrm{Fe}_{2} \mathrm{O}_{3}$ & 1.43 & 0.96 & 0.98 & 1.93 & 1.64 & 1.22 & 2.52 & 7.20 & 2.50 & 3.16 \\
\hline $\mathrm{TiO}_{2}$ & 0.10 & 0.14 & 0.08 & 0.18 & 0.11 & 0.07 & 0.17 & 0.93 & 0.24 & 0.30 \\
\hline $\mathrm{Al}_{2} \mathrm{O}_{3}$ & 6.69 & 8.98 & 6.87 & 9.47 & 11.68 & 10.19 & 6.11 & 11.90 & 5.06 & 12.57 \\
\hline $\mathrm{MnO}$ & 0.01 & 0.01 & 0.01 & 0.02 & 0.02 & 0.01 & 0.03 & 0.10 & 0.01 & 0.01 \\
\hline $\mathrm{CaO}$ & 0.47 & 1.43 & 0.82 & 5.51 & 1.09 & 1.33 & 0.87 & 8.57 & 0.62 & 1.56 \\
\hline $\mathrm{MgO}$ & 0.40 & 1.37 & 0.70 & 1.27 & 0.62 & 1.02 & 0.88 & 3.32 & 0.80 & 1.24 \\
\hline $\mathrm{K}_{2} \mathrm{O}$ & 1.92 & 1.28 & 1.92 & 2.19 & 3.16 & 3.17 & 0.61 & 0.77 & 0.48 & 2.09 \\
\hline $\mathrm{Na}_{2} \mathrm{O}$ & 1.15 & 1.50 & 1.34 & 2.02 & 3.20 & 2.00 & 0.86 & 2.88 & 0.76 & 2.09 \\
\hline $\mathrm{SiO}_{2}$ & 86.21 & 82.65 & 85.43 & 71.35 & 76.58 & 80.10 & 85.33 & 57.79 & 87.73 & 73.80 \\
\hline $\mathrm{SO}_{3}$ & 0.05 & 0.10 & 0.10 & 0.15 & 0.03 & 0.11 & 0.07 & 0.09 & 0.05 & 0.08 \\
\hline $\mathrm{Cl}$ & 0.15 & 0.05 & 0.18 & 0.43 & 0.02 & 0.16 & 0.01 & 0.07 & 0.04 & 0.07 \\
\hline $\mathrm{P}_{2} \mathrm{O}_{5}$ & trace & 0.05 & 0.04 & 0.07 & 0.03 & 0.03 & 0.04 & 0.15 & 0.05 & 0.12 \\
\hline $\mathrm{CO}_{2}$ & - & - & - & 3.05 & - & - & - & 2.97 & - & - \\
\hline $\mathbf{N}$ & n. d. & n. d. & n. d. & n. d. & n. d. & n. d. & n. d. & n. d. & n. d. & n. d. \\
\hline
\end{tabular}

Table 4. Chemical composition of the deposits on sea-salt-free and dry basis (calculated from Table 3 ).

\begin{tabular}{|c|c|c|c|c|c|c|c|c|c|c|}
\hline Sample No. & 101 & 110 & 102 & 103 & 104 & 109 & 105 & 106 & 107 & 108 \\
\hline $\mathrm{Fe}_{2} \mathrm{O}_{3}$ & $1.4 \%$ & $0.96^{\%}$ & $0.99^{\%}$ & $1.96^{\%}$ & $1.65^{\%}$ & $1.23^{\%}$ & $2.54^{\%}$ & $7.24^{\%}$ & $2.51^{\%}$ & $3.18^{\%}$ \\
\hline $\mathrm{TiO}_{2}$ & 0.10 & 0.14 & 0.08 & 0.18 & 0.11 & 0.07 & 0.17 & 0.94 & 0.24 & 0.30 \\
\hline $\mathrm{Al}_{2} \mathrm{O}_{3}$ & 6.75 & 9.02 & 6.93 & 9.63 & 11.77 & 10.26 & 6.15 & 11.97 & 5.08 & 12.66 \\
\hline $\mathrm{MnO}$ & 0.01 & 0.01 & 0.01 & 0.02 & 0.02 & 0.01 & 0.03 & 0.10 & 0.01 & 0.01 \\
\hline $\mathrm{CaO}$ & 0.47 & 1.44 & 0.82 & 5.59 & 1.10 & 1.34 & 0.88 & 8.62 & 0.62 & 1.57 \\
\hline $\mathrm{MgO}$ & 0.38 & 1.37 & 0.69 & 1.24 & 0.62 & 1.01 & 0.89 & 3.33 & 0.80 & 1.24 \\
\hline $\mathrm{K}_{2} \mathrm{O}$ & 1.94 & 1.29 & 1.94 & 2.22 & 3.19 & 3.19 & 0.61 & 0.77 & 0.48 & 2.10 \\
\hline $\mathrm{Na}_{2} \mathrm{O}$ & 1.05 & 1.47 & 1.22 & 1.73 & 3.22 & 1.89 & 0.86 & 2.85 & 0.73 & 2.05 \\
\hline $\mathrm{SiO}_{2}$ & 86.92 & 83.04 & 86.21 & 72.56 & 77.19 & 80.66 & 85.92 & 58.13 & 88.07 & 74.31 \\
\hline $\mathrm{SO}_{3}$ & 0.03 & 0.09 & 0.08 & 0.10 & 0.03 & 0.09 & 0.07 & 0.08 & 0.05 & 0.07 \\
\hline $\mathrm{P}_{2} \mathrm{O}_{3}$ & trace & 0.05 & 0.04 & 0.07 & 0.03 & 0.03 & 0.04 & 0.15 & 0.05 & 0.12 \\
\hline $\mathrm{CO}_{2}$ & - & - & - & 3.10 & - & - & - & 2.99 & - & - \\
\hline $\mathbf{N}$ & n. d. & n. d. & n. d. & n. d. & n. d. & n. d. & n. d. & n. d. & n. d. & n. d \\
\hline $\mathrm{Na}_{2} \mathrm{O}+\mathrm{K}_{2} \mathrm{O}$ & 2.99 & 2.76 & 3.16 & 3.95 & 6.41 & 5.08 & 1.47 & 3.62 & 1.21 & 4.15 \\
\hline $\mathrm{K}_{2} \mathrm{O} / \mathrm{Na}_{2} \mathrm{O}$ & 1.85 & 0.88 & 1.59 & 1.28 & 0.99 & 1.69 & 0.71 & 0.27 & 0.66 & 1.02 \\
\hline
\end{tabular}

* We performed this calculation on the basis of the same assumption as in the previous paper (ISHIBASHI and UEDA, 1955 a). 
such as Samples 109, 105 and 107, are exceedingly high in $\mathrm{SiO}_{2}$ and low on the whole in $\mathrm{Fe}_{2} \mathrm{O}_{3}, \mathrm{TiO}_{2}, \mathrm{Al}_{2} \mathrm{O}_{3}, \mathrm{MnO}, \mathrm{CaO}$, $\mathrm{MgO}$, etc. Among these deposits, it is remarkable that Sample 101 is high in $\mathrm{SiO}_{2}$ and low in $\mathrm{Al}_{2} \mathrm{O}_{3}, \mathrm{CaO}$ and $\mathrm{MgO}$; Sample 110, low in $\mathrm{Fe}_{2} \mathrm{O}_{3}$; Sample 102, high in $\mathrm{SiO}_{2}$ and low in $\mathrm{Fe}_{2} \mathrm{O}_{3}$ and $\mathrm{Al}_{2} \mathrm{O}_{3}$; Samples 105 and 107, high in $\mathrm{SiO}_{2}$ and low in $\mathrm{Al}_{2} \mathrm{O}_{3}$ and alkalies. On the other hand, Sample 106 is entirely different from the other sands in this report and similar to the blackish sands from Sagami Bay (UEDA, $1956 \mathrm{c}$ ) both in its appearance and chemical composition. Namely, it is exceedingly low in $\mathrm{SiO}_{2}$ and $\mathrm{K}_{2} \mathrm{O}$, and considerably high in $\mathrm{Fe}_{2} \mathrm{O}_{3}, \mathrm{TiO}_{2}, \mathrm{CaO}, \mathrm{MgO}$, etc.

As for alkalies, the $\mathrm{K}_{2} \mathrm{O}$ content ranges $0.48 \sim 3.19 \%$, being considerably high in Samples 104 and 109, and exceedingly low in Samples 105, 106 and 107. The $\mathrm{Na}_{2} \mathrm{O}$ content is high in Samples 104 and 106, but low in most of the others. In consequence, there are comparatively many samples in which the $\mathrm{Na}_{2} \mathrm{O}+\mathrm{K}_{2} \mathrm{O}$ content is low.

Generalized Considelation on the Analytical Results of all the Somples from all the Sea-coasts of Japan Proper

Now, as we have analysed 110 kinds of deposits, i.e. 30 kinds of muds* and 80 kinds of sands, which are all samples collected at sll the sea-coasts of Japan Proper, we have summarized the analytical results, as shown in Table 5, in which the average chemical composition of all samples and the maximum, minimum and average values of each chemical constituents of all muds and sands are described, respectively. The average chemical ccmposition of the shallow-water deposits of Korea, red clays and rocks is also recited for comparison in this table.

Based on the data in Table 5 and the analytical results of all samples so far reported, the author has discussed the distribution of the main constituents in these beposits, comparing their average values with those of the shallow-water deposits of Korea, red clays, igneous rocks, shales and sandstones.

1. $\mathrm{SiO}_{2}$ : The maximum $\mathrm{SiO}_{2}$ content in * Sandy muds are also included. muds is $83.82 \%$ of Sample 75 collected at Nishitonda, Wakayama Prefecture, and the minimum is $53.19 \%$ of Sample 22 at Takahama, Aichi Prefecture; the maximum in sands is $89.62 \%$ of Sample 70 at Akashi, Hyōgo Prefecture, and the minimum is 31.24\% of Sample 37 at Funagawaminato, Akita Prefecture. As for the muds, they were collected mostly at Aichi, Okayama and Hiroshima Prefectures, of which the muds of Aichi are relatively sandy and so many of them are rich in $\mathrm{SiO}_{2}$, having above $70 \% \mathrm{SiO}_{2}$, while those of Okayama and Hiroshima Prefectures are generally low in it. Of the muds from other districts, those of Wakayama Prefecture are exceedingly high in $\mathrm{SiO}_{2}$. As for the $\mathrm{SiO}_{2}$ content in sands, it is mostly above $70 \%$, being especially high in many of the deposits from those prefectures as Hiroshima, Yamaguchi, Kyōto, Mie, Wakayama, Ōsaká, etc., while low in relatively small numbers of sands, being about $60 \%$ or less, in those from Aomori, Iwate, Kanagawa, Shizuoka, Tottori, etc. The average $\mathrm{SiO}_{2}$ content in muds amounts to $66.49 \%$, which is similar to that in shallowmuds from Kore', and higher than in red clays, igneous rocks and shales, but lower than in sandstones. The average $\mathrm{SiO}_{2}$ content in sands amounts to $73.20 \%$, which is almost the same as that in sands from korea, and higher than in red clays, igneous rocks and shales, but lower than in sandstones.

2. $\mathrm{Fe}_{2} \mathrm{O}_{3}$ : The maximum $\mathrm{Fe}_{2} \mathrm{O}_{3}$ content in muds is $7.29 \%$ of Sample 52 collected at Kojima Bay, and the minimum is $1.79 \%$ of Sample 76 at Shinjō, Wakayama Prefecture; the maximum in sands is $13.00 \%$ of Sample 43 at Rokukasho, Aomori Prefecture, and the minimum is $0.46 \%$ of Sample 63 at Nago, Yamaguchi Prefecture. As for the $\mathrm{Fe}_{2} \mathrm{O}_{3}$ content in muds, it ranges $3 \sim 6 \%$ in most of the deposits, though it amounts to about $7 \%$ in several deposits from Miyagi, Aichi and Okayama Prefectures, and is less than $2 \%$ in the muds from Wakayama Prefecture. As for the sands, the $\mathrm{Fe}_{2} \mathrm{O}_{3}$ content is exceedingly high, amounting to about $10 \%$, in some of the deposits from Aomori, Iwate, Kanagawa and Shizuoka Prefectures, and 
S. Ueda : Chemical Studies on the Ocean (LXV)

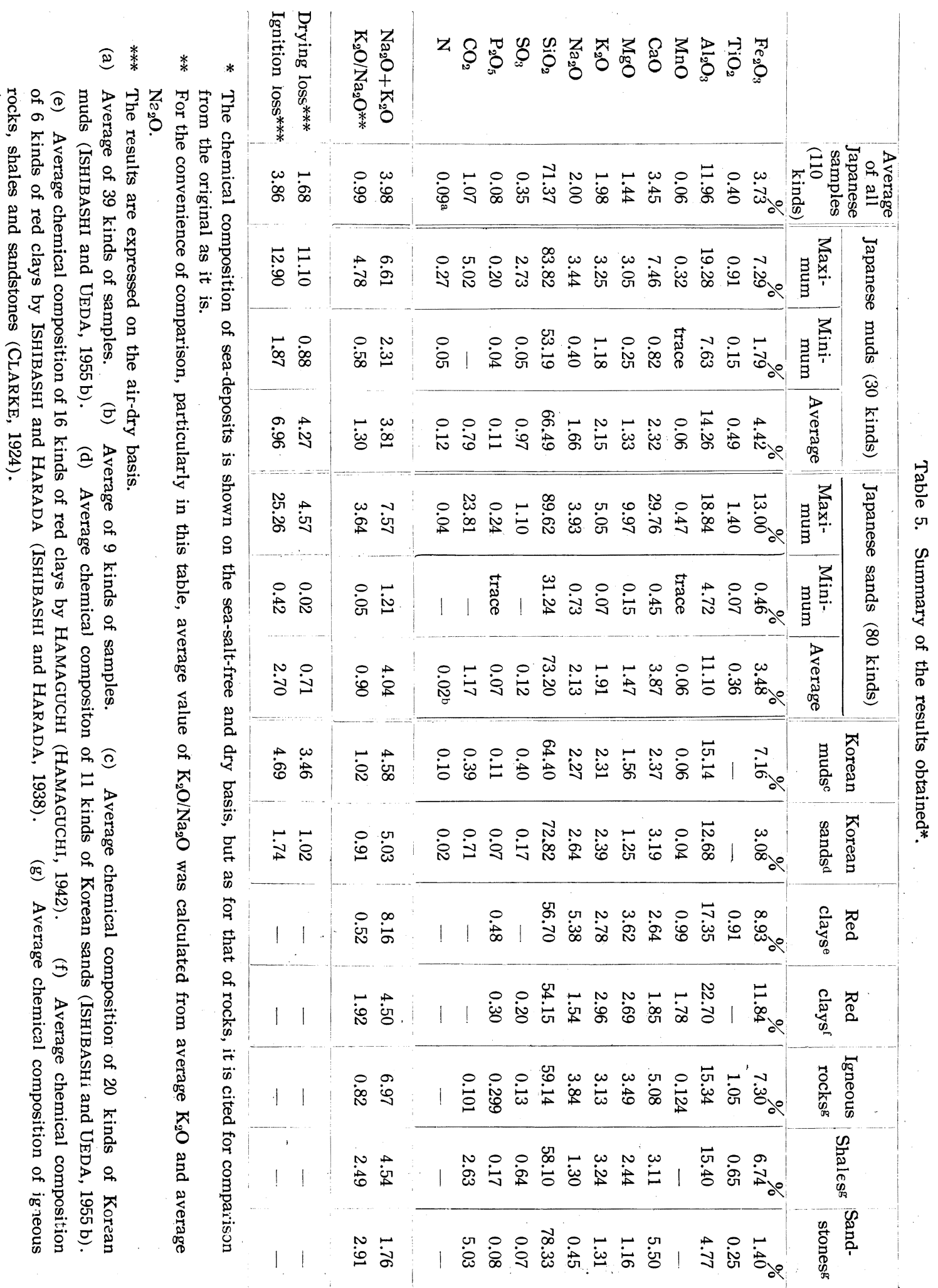


exceedingly low, being about 1\%, in many of the deposits from Hiroshima, Yamaguchi, Ōsaka, etc. The average $\mathrm{Fe}_{2} \mathrm{O}_{3}$ content in muds amounts to $4.42 \%$, which is lower than in Korean muds, red clays, igneous rocks and shales, but higher than in sandstones. The average in sands amounts to $3.48 \%$, which is similar to that in Korean sands and lower than in red clays, igneous rocks and shales, but higher than in sandstones.

3. $\mathrm{TiO}_{2}$ : The maximum $\mathrm{TiO}_{2}$ content in muds is $0.91 \%$ of Sample 52 collected at Kojima Bay, and the minimum is $0.15 \%$ of Sample 21 at Terazu, Aichi Prefecture; the maximum in sands is $1.40 \%$ of Sample 40 at Ushirogata, Aomori Prefecture, and the minimum is $0.07 \%$ of Samples 79 and 109 which were collected at Ōyodo, Mie Prefecture and Miyazu, Kyōto Prefecture, respectively. As to the relation between the $\mathrm{TiO}_{2}$ content and those of the other constituents is not so clear, but there is a tendency in some degree that $\mathrm{TiO}_{2}$ is generally high in the deposits having low $\mathrm{SiO}_{2}$ and high $\mathrm{Fe}_{2} \mathrm{O}_{3}$, and it is low in those having high $\mathrm{SiO}_{2}$ and low $\mathrm{Fe}_{3} \mathrm{O}_{3}$. The average $\mathrm{TiO}_{2}$ contents in muds and sands are $0.49 \%$ and $0.36 \%$, respectively, which are lower than in red clays, igneous rocks and shales, but higher than in sandstones.

4. $\mathrm{Al}_{2} \mathrm{O}_{3}$ : The maximum $\mathrm{Al}_{2} \mathrm{O}_{3}$ content in muds is $19.28 \%$ of Sample 51 collected at Kojima Bay, and the minimum is $7.63 \%$ of Sample 23 at Handa, Aichi Prefecture; the maximum in sands is $18.84 \%$ of Sample 89 at Usami, Shizuoka Prefecture, and the minimum is $4.72 \%$ of Sample 70 at Akashi, Hyōgo Prefecture. The $\mathrm{Al}_{2} \mathrm{O}_{3}$ content is generally high in muds which are clayey, and considerably low in sandy muds which were collected at Aichi and Wakayama Prefectures. As for the $\mathrm{Al}_{2} \mathrm{O}_{3}$ content in sands, it is considerably lower than in muds, and only in several sands it is above $15 \%$, most of them having about $13 \%$ or lower. And it is generally high in the sands with low content of $\mathrm{SiO}_{2}$ collected from Tottori, Miyagi, Kanagawa, Shizuoka Prefectures, etc., while it is low in those with high content of $\mathrm{SiO}_{2}$ obtained from Hiroshimä, Yamaguchi, Kyōto, Mie, Wakayama, Ōsaka, etc. Though there are some exceptions, the $\mathrm{Fe}_{2} \mathrm{O}_{3}$ and $\mathrm{Al}_{2} \mathrm{O}_{3}$ contents are in general high in the deposits of low $\mathrm{SiO}_{2}$ content and low in those of high $\mathrm{SiO}_{2}$ content. The average $\mathrm{Al}_{2} \mathrm{O}_{3}$ content in muds amounts to $14.26 \%$, which is similar to that in Korean muds, igneous rocks and shales, and lower than in red clays, but higher than in sandstones. The average in sands amounts to $11.10 \%$, which is slightly lower than in Korean sands, and lower than in red clays, igneous rocks and shales, but higher than in sandstones.

5. $\mathrm{MnO}$ : The maximum $\mathrm{MnO}$ coritent in muds is $0.32 \%$ of Sample 51 collected at Kojima Bay, and the minimum is found in the trace of Sample 75 at Nishitonda, Wakayama Prefecture; the maximum in sands is $0.47 \%$ of Sample 43 at Rokukasho, Aomori Prefecture, and the minimum is in the trace of Sample 59 at Nakanoseki, Yamaguchi Prefecture. The MnO content in the shallow-water deposits is exceedingly low on the whole, most of them having less than $0.1 \%$ and it is found nearly as trace in many samples. The deposits whose $\mathrm{MnO}$ content amounts to $0.1 \%$ or more, are only $14 \%$ of the total samples, which are mostly the deposits with high content of $\mathrm{Fe}_{2} \mathrm{O}_{3}$ collected from Aomori, Iwate, Kanagawa, Shizuoka, Okayama Prefectures, etc. The average $\mathrm{MnO}$ content both in muds and in sands is $0.06 \%$, which is sim:lar to that in Korean deposits, and lower than in red clays and igneous rocks, especially lower than in red clays. Thus shallow-water deposits are remarkably different from deepsea deposits in the $\mathrm{MnO}$ content.

6. $\mathrm{CaO}$ and $\mathrm{MgO}$ : The maximum content of $\mathrm{CaO}$ in muds is $7.46 \%$ of Sample 80 collected at Funakoshi, Mie Prefecture and that of $\mathrm{MgO}$ is $3.05 \%$ of Sample 55 at Yorishima, Okayama prefecture; the minimum contents of $\mathrm{CaO}$ and $\mathrm{Mgo}$ are, respectively, $0.82 \%$ of Sample 75 at Nishitonda, Wakayama Prefecture and $0.25 \%$ of Sample 20 at Oitsu, Aichi Prefecture; the maximum contents of $\mathrm{CaO}$ and $\mathrm{MgO}$ in sands are 29.76\% of Sample 63 at Nago, Yamaguchi Prefecfure and 9.97\% 
of Sample 43 at Rokukasho, Aomori Prefecture, respectively; the minimum contents of $\mathrm{CaO}$ and $\mathrm{MgO}$ are $0.45 \%$ of Sample 29 at Saizaki, Hiroshima Prefecture and 0.15\% of Sample 70 at Akashi, Hyōgo Prefecture, respectively. As for the $\mathrm{CaO}$ content, it is high in the deposites which are rich in carbonates. So, if we recalculate the $\mathrm{CaO} \%$ based on the $\mathrm{CaCO}_{3}$-free samples, assuming that the shell fragments consist of $\mathrm{CaCO}_{3}$ alone, and $\mathrm{CO}_{2}$ in the analyses results from shell fragments only, it is mostly high in the sands with relatively low content of $\mathrm{SiO}_{2}$ which were collected at Aomori, Iwate, Kanagawa, Shizuoka, Tottori Prefectures, etc., and is low on the whole in those with high content of $\mathrm{SiO}_{2}$, such as the muds from Aichi and Wakayama and the sands from Hiroshima, Yamaguchi, Mie, Ōsaka. Kyōto, etc. And the $\mathrm{MgO}$ content is also generally high in those with low content of $\mathrm{SiO}_{2}$ and low in those with high content of $\mathrm{SiO}_{2}$. The average $\mathrm{CaO}$ and $\mathrm{MgO}$ contents in muds amount to $2.32 \%$ and $1.33 \%$, respectively, and those in sands amount to $3.87 \%$ and $1.47 \%$, respectively. The $\mathrm{CaO}$ in muds is lower than in igneous rocks, shales and sandstones, and similar in Korean muds and red clays. The $\mathrm{CaO}$ in sands is higher than in Korean sands, red clays and shales, but lower than in igneous rocks and sandstones. The $\mathrm{MgO}$ in muds and sands is lower than in red clays, igneous rocks and shales, and similar in Korean deposits and sandstones. The average content of $\mathrm{CaO}$ is lower than that of $\mathrm{MgO}$ in red clays, while as for shallow-water deposits the former is similar to* or higher*** than the latter even on the $\mathrm{CaCO}_{3}$-free basis.

7. $\mathrm{P}_{2} \mathrm{O}_{5}$ : The maximum $\mathrm{P}_{2} \mathrm{O}_{5}$ content in muds is $0.20 \%$ of Samples 19 and 25 which were collected at Tahara and Shimonoishiki, Aichi Prefecture, respectively, the minimum being $0.04 \%$ of Sample 76 at Shinjō, Wakayama Prefecture; the maximum in sands is $0.24 \%$ of Sample 43 at Rokukasho, Aomori Prefecture, and the minimum is found in the traces of Samples 29, 79 and 101 which were collected at Saizaki, Hiroshima ; * in the muds. ** in the sands.
Ōyodo, Mie ; Tajiri, Ōsaka Prefecture, respectively. The average $\mathrm{P}_{2} \mathrm{O}_{5}$ content in muds is $0.11 \%$ and that in sands is $0.07 \%$, both of which are the same as in Korean muds and sands, respectively, and lower than in red clays, igneous rocks and shales, but similar in sandstones.

8. $\mathrm{K}_{2} \mathrm{O}$ and $\mathrm{Na}_{2} \mathrm{O}$ :

$\mathrm{K}_{2} \mathrm{O}$ : The maximum $\mathrm{K}_{2} \mathrm{O}$ content in muds is $3.25 \%$ of Sample 26 collected at Shingai, Hiroshima Prefecture, and the minimum is 1.18\% of Sample 75 at Nishitonda, Wakayama Prefecture; the maximum in sands is $5.05 \%$ of Sample 30 at Tadanoumi, Hiroshima Prefecture, the minimum being $0.07 \%$ of Sample 89 at Usami, Shizuoka Prefecture. As for the $\mathrm{K}_{2} \mathrm{O}$ content in muds, it is higher in the deposits from Hiroshima Prefecture, being about $2 \sim 3 \%$ in all the deposits, while in the deposits from Aichi, Okayama and most of other prefectures, there are samples in which it is less than $2 \%$. As for the $\mathrm{K}_{2} \mathrm{O}$ content in sands, it is highest in those from Hiroshima Prefecture, being above $3 \%$ in all the samples, amounting to about $4 \sim 5 \%$ in some of them, and higher in those from Yamaguchi and Shimane Prefectures, being above 3\% in many of them, and is relatively high in those from Ishikawa, Toyama, Niigata, Yamagata, Hyōgo, Tottori, Kyōto Prefectures, etc., being about $2 \sim 3 \%$ in many of them. On the other hand, it is remarkably low in many of the sands from Aomori, Miyagi, Chiba, Kanagawa, Wakayama, Mie, Fukui, etc., being only $1 \%$ or less. The average $\mathrm{K}_{2} \mathrm{O}$ content in muds amounts to $2.15 \%$, which is similar to that in Korean muds, and lower than in red clays, igneous rocks and shales, but higher than in sandstones. The average in sands amounts to $1.91 \%$, which is lower than in Korean sands, red clays, igneous rocks and shales, but higher than in sandstones.

$\mathrm{Na}_{2} \mathrm{O}$ : The maximum $\mathrm{Na}_{2} \mathrm{O}$ content in muds is $3.44 \%$ of Sample 32 collected at Shimono, Hiroshima Prefecture, and the minimum is $0.40 \%$ of Sample 19 at Tahara, Aichi Prefecture; the max:mum in sands is $3.93 \%$ of Sample 68 at Yodoe, Tottori 
Prefecture, the minimum being $0.73 \%$ of Sample 107 at Obama, Fukui Prefecture. The average $\mathrm{Na}_{2} \mathrm{O}$ content in muds amounts to $1.66 \%$, which is similar to that in red clays by IsHiBASH and HARADA and shales, and lower than in Korean muds, red clays by HAMAGUCHI and igneous rocks, but higher than in sandstones. The average in sands amounts to $2.13 \%$, which is lower than in Korean sands, red clays by HAMAGUCHI and igneous rocks, but higher than in red clays by IsHIBASHI and HARADA, shales and sandstones. Especially the $\mathrm{Na}_{2} \mathrm{O}$ content is lower in shallow-water deposits than in red clays by HamaguchI.

$\mathrm{Na}_{2} \mathrm{O}+\mathrm{K}_{2} \mathrm{O}$ : The maximum $\mathrm{Na}_{2} \mathrm{O}+\mathrm{K}_{2} \mathrm{O}$ content in muds is $6.61 \%$ of Sample 32 collected at Shimono, Hiroshima Prefecture, and the minimum is 2.31\% of Sample 19 at Tahara, Aichi Prefecture; the maximum in sands is $7.57 \%$ of Sample 30 at Tadanoumi, Hiroshima Prefecture, and the minimum is $1.21 \%$ of Sample 107 at Obama, Fukui Prefecture. The $\mathrm{Na}_{2} \mathrm{O}+\mathrm{K}_{2} \mathrm{O}$ content is relatively high in the deposits from Hiroshima, Shimane, Tottori, Ishikawa, Toyama, Niigata, Yamagata and Ibaraki Prefectures, being above $4 \%$ in all the samples, while in those from Aomori, Miyagi, Chiba, Kanagawa, Mie, Ōsaka, Oknyama, etc., it is generally low, being less than $3 \%$ in many of them. The average $\mathrm{Na}_{2} \mathrm{O}+\mathrm{K}_{2} \mathrm{O}$ content in muds is $3.81 \%$ and that in sands is $4.04 \%$, which are slightly lower than in Korean deposits, red clays by Ishibashi and HARADA and shales, and lower than in red clays by HAMAguchi and igneous rocks, but higher than in sandstones.

$\mathrm{K}_{2} \mathrm{O} / \mathrm{Na}_{2} \mathrm{O}$ : The maximum $\mathrm{K}_{2} \mathrm{O} / \mathrm{Na}_{2} \mathrm{O}$ value in muds is 4.78 of Sample 19 collected at Tahara, Aichi Prefecture, and the minimum is 0.58 of Sample 48 at Orikasa, Iwate Prefecture; the maximum in sands is 3.64 of Sample 60 at Higashikiwa, Yamaguchi Prefecture, the minimum being 0.05 of Sample 88 at Sakawa, Kanagawa Prefecture. The average $\mathrm{K}_{2} \mathrm{O} / \mathrm{Na}_{2} \mathrm{O}$ value in muds is 1.30 , which is similar to that in Korean muds, and lower than in red clays by IsHIBASHI and HARADA, shales and sandstones, but higher than in red clays by HAMAGUCH and igneous rocks. The average in sands is 0.90 , which is similar to that in Korean sands and igneous rocks, and lower than in red clays by IshibashI and HARADA, shales and sandstones, but higher than in red clays by Hamaguchi.

The author wishes to express his sincere thanks to Prof. M. IsHibashi of the Kyoto University for his kind guidance and encouragement throughout this investigation. Thanks are also due to Assist. Prof. Y. KASENO of the Kanazawa University for his useful advices and further, to Messrs, $K$. Sakai, E. Takao, N. Morita, K. Kanamasu, M. Noda, K. ŌTsúka, Y. Tsuji, S. MoritsuGu, Y. Mizue and S. Fujita who presented us with many valuable samples.

\section{References}

ClARKe, F. W., 1924 :

"The Data of Geochemistry", U. S. Geol. Survey, Bull. 770, 5. Ed., p. 34, Washington.

HAMAGUCHI, H., 1942 :

"Chemical 1nves tirations of Deep-sea Deposits",

J. Chem. Soc. Japan, 63, 1689.

ISHIBASHI, M. and Y. HARADA, 1938:

"Determination of Chemical Compositions of Red Clay and Radioralian Ooze in the Pacific Ocean". ibid., 59, 569.

ISHIBASHI, M. and S. UEDA, $1955 \mathrm{a}$ :

"On the Chemical Constituents of the Shallowwater Deposits along the Sea-coasts of Korea", Bull. Inst. Chem. Res., Kyoto Univ., 33, 165.

- and - $1955 \mathrm{~b}$ :

"On the Chemical Constituents of the Shallowwater Deposits along the Sea-coasts of Korea", ibid., 33, 170.

— and,$- 1956 \mathrm{a}$ :

" On the Chemical Constituents of the Shallowwater Deposits along the Sea-coasts of Ishikawa and Toyama Prefectures", ibid., 34, 117.

— and - $1956 \mathrm{~b}$ :

"On the Chemical Constituents of the Shallowwater Deposits along the Sea-coast of Aichi Prefecture", ibid., 34, 122.

$\longrightarrow$ and,$- 1956 \mathrm{c}$ :

"On the Chemical Constituents of the Shallowwater Deposits along the Sea-coasts of Niigata, Yamagata and Akita Prefectures", ibid., 34, 127. - and $-1956 \mathrm{~d}$ :

"On the Chemical Constituents of the Shallow- 
water Deposits along the Sea-coast of Hiroshima

Prefecture", ibid., 34, 132. and,$- 1956 \mathrm{e}$ :

" On the Chemical Constituents of the Shallowwater Deposits along the Sea-coasts of Aomori and Iwate Prefectures ", ibid., 34, 137.

- and -, $1956 \mathrm{f}$ :

" On the Chemical Constituents of the Shallowwater Deposits along the Sea-coast of Okayama Prefecture", ibid., 34, 235.

- and - $1956 \mathrm{~g}$ :

"On the Chemical Constituents of the Shallowwater Deposits along the Sea-coasts of Yamaguchi and Shimane Prefectures ", ibid., 84, 240.

ISHIBASHI, M., S. UEDA and Y. YAMAMOTO, 1956 :

" On the Chemical Constituents of the Shallow- water Deposits along the Sea-coasts of Tottori and Hyōgo Prefectures", ibid., 34, 245.

UEDA, S., 1956 a :

" On the Chemical Constituents of the Shallow. water Deposits along the Sea-coasts of Miyagi, Fukushima and Ibaraki Prefectures", Journ. Oceanogr. Soc. Japan, 12, 89.

$\longrightarrow, 1956 \mathrm{~b}$ :

"On the Chemical Constituents of the Shallowwater Deposits along the Sea-coasts of Wakayama and Mie Prefectures", ibid., 12, 81.

- $1956 \mathrm{c}$ :

" On the Chemical Constituents of the Shallow. water Deposits along the Sea-coasts of Chiba, Kanagawa and Shizuoka Prefectures ", ibid., 12, 85. 